\title{
Ontogeny of Thyrotropin Releasing Hormone and Precursor Peptide in the Rat
}

\author{
YOZEN FUSE, DANIEL H. POLK, ROBERT W. LAM, AND DELBERT A. FISHER \\ Department of Neonatology, Toho University School of Medicine, Ohta-Ku, Tokyo, 143 Japan [Y.F.] and \\ Harbor-UCLA Medical Center, Torrance, California 90509 [D.H.P., R.W.L., D.A.F.]
}

\begin{abstract}
Thyrotropin releasing hormone (TRH) and its precursor peptide pGlu-His-Pro-Gly (TRH-Gly) were measured in serum and in a variety of tissues of developing rats using specific RIA. TRH and TRH-Gly immunoreactivities were detected in most tissues. TRH concentrations were highest in pancreas, in which mean ( \pm SEM) TRH concentrations were $138 \pm 20 \mathrm{pmol} / \mathrm{g}$ wet tissue $2 \mathrm{~d}$ before birth and $644 \pm 80$ and $586 \pm 86 \mathrm{pmol} / \mathrm{g}$, respectively, 2 and $5 \mathrm{~d}$ after birth. Hypothalamic TRH levels gradually increased from $4 \mathrm{~d}$ before birth $(12 \pm 2.5 \mathrm{pmol} / \mathrm{g})$ to $77 \mathrm{~d}$ of postnatal age ( $348 \pm 33 \mathrm{pmol} / \mathrm{g}$ ). Hypothalamic concentrations were lower than levels in pancreas until $13 \mathrm{~d}$ of age. The mean serum TRH level at $2 \mathrm{~d}$ was $80 \pm 20 \mathrm{pmol} /$ $\mathrm{L}$ and fell to the adult range by $21 \mathrm{~d}$.
\end{abstract}

TRH-Gly concentrations were highest in small gut (371 $\pm 64 \mathrm{pmol} / \mathrm{g}$ ) during the neonatal period, falling gradually to adult levels $(33 \pm 4.8 \mathrm{pmol} / \mathrm{g})$ by $35 \mathrm{~d}$. Mean hypothalamic TRH-Gly concentrations increased to a peak of $62 \pm$ $4.5 \mathrm{pmol} / \mathrm{g}$ at $13 \mathrm{~d}$, falling thereafter. High TRH-Gly concentrations $(>100 \mathrm{pmol} / \mathrm{g})$ also were observed in pancreas (at d 2), kidney, and pituitary gland (at d 21). Serum TRH-Gly concentrations were highest (mean $417 \pm 26$ $\mathrm{pmol} / \mathrm{L}$ ) on the 2 nd postnatal day and gradually decreased to the adult level by $35 \mathrm{~d}$. Changes in the TRH-Gly/TRH ratio were inversely correlated with tissue TRH concentrations in hypothalamus, pancreas, and liver. Our results suggest that 1) tissue levels of TRH-Gly and TRH are developmentally regulated, 2) the conversion of TRH-Gly to TRH varies among tissues, and 3) the major tissue site of TRH biosynthesis changes during development from liver during fetal life to pancreas in the neonatal period and to hypothalamus in the adult. The consistently high TRH-Gly/TRH ratio in serum suggests that the circulating peptides are derived from multiple and predominantly nonhypothalamic tissue sources. (Pediatr Res 30: 28-33, 1991)

\section{Abbreviations}

TRH, thyrotropin releasing hormone, pGlu-His-Pro- $\mathrm{NH}_{2}$ TRH-Gly, pGlu-His-Pro-Gly

prepro, precursor protein

TRH (pGlu-His-Pro- $\mathrm{NH}_{2}$ ) is derived from a large prepro-TRH protein (1). Rat hypothalamic proTRH is a 255-amino acid protein containing five copies of the TRH progenitor sequence, Gln-His-Pro-Gly. ProTRH is sequentially cleaved to a variety of

Received August 13, 1990; accepted February 22, 1991.

Correspondence and reprint requests: Daniel H. Polk, Perinatal Laboratories, Harbor-UCLA Medical Center, RB-1, 1000 West Carson Street, Torrance, CA 90509 .

Supported by Grants HD 04270-21 and HD-00746-03. precursor fragments by trypsin-like enzymes (2). A C-terminal glycine extended form of TRH (TRH-Gly) is the immediate TRH precursor and is processed to TRH via amidation of the proline residue using the C-terminal glycine residue as the amide donor (3) after cyclization of the N-terminal glutamine (4). Colocalization of TRH and TRH-Gly has been reported in both neural and extraneural tissues of adult rats (5).

In the perinatal period, important changes in TRH metabolism have been reported. The serum TRH concentration is relatively high in neonatal rats (6) at least in part because of low levels of TRH degrading activity in newborn serum (7). The TRH contents of pancreas and other gut tissues exceed hypothalamic levels and circulating TRH seems largely derived from these gut tissues $(8,9)$. There are several recent ontogenic studies of other TRH precursor peptides in rat pancreas $(10,11)$, but little data regarding the ontogenesis of tissue TRH-Gly concentrations in other tissue sites. In the present study, we measured TRH and TRH-Gly concentrations in a variety of fetal and neonatal rat tissues to further characterize the developmental changes in TRH synthesis and metabolism.

\section{MATERIALS AND METHODS}

Subjects and Sampling. Adult and timed pregnant Wistar rats, obtained from Harlan Sprague Dawley Inc. (Indianapolis, IN), were maintained in an air conditioned environment (at $21^{\circ} \mathrm{C}$, $55 \%$ humidity) with rat food and water available ad libitum. Lights were on from 0600 to $1800 \mathrm{~h}$. Adult animals were housed one to a cage and pups were housed with their mothers. The day vaginal plugs and sperm were found was taken as $\mathrm{d} 0$ of pregnancy. The day of parturition was the 1st postnatal day of age. Animals were studied from $6 \mathrm{~d}$ before birth to $35 \mathrm{~d}$ after birth, and body weights ranged from 0.5 to $145 \mathrm{~g}$ (Table 1). Because individual organs could not be studied in the early fetal period, organs from several littermates were pooled and studied collectively. The number of fetal littermates combined for each pool as well as the number of pools studied are indicated in Table 1.

Between 0900 and $1200 \mathrm{~h}$, adult rats were killed by decapitation and trunk blood was collected in precooled glass tubes. Neonatal rats were decapitated immediately after collecting blood by heart puncture. Fetuses were removed after hysterotomy, blotted dry, weighed, and then decapitated. Organs were excised and blotted to remove excess blood. Samples were weighed and placed in cold $1 \mathrm{M}$ acetic acid $(20 \% \mathrm{wt} / \mathrm{vol}$, minimum $1 \mathrm{~mL}$ ). Except in the youngest fetuses, the whole brain was divided into cerebrum, hypothalamic regions, and cerebellum with brain stem. The hypothalamic fragment was delimited in the sagittal plane by the posterior margin of the optic chiasm and the anterior portion of the mammillary body; the lateral margins were the hypothalamic sulci. The dorsal extent of the cut was $2 \mathrm{~mm}$. Digestive organs were divided into stomach, duodenum, and small and large intestine; contents were washed out with chilled distilled water. Intestinal tissues were not able to be separated into duodenum, and small and large bowel earlier 
Table 1. Age and body weight of animals*

\begin{tabular}{ccc}
\hline Age $(\mathrm{d}) \dagger$ & Body wt $(\mathrm{g})$ & $n \ddagger$ \\
\hline-6 & $0.52 \pm 0.01$ & $5(6)$ \\
-4 & $1.1 \pm 0.1$ & $5(5)$ \\
-2 & $3.7 \pm 0.1$ & $5(4)$ \\
2 & $7.3 \pm 0.2$ & 9 \\
5 & $9.4 \pm 0.2$ & 6 \\
13 & $26 \pm 1.2$ & 5 \\
21 & $47 \pm 3.4$ & 7 \\
35 & $145 \pm 3.1$ & 6 \\
\hline
\end{tabular}

$*$ Values are mean \pm SEM.

$\dagger$ Birth $=\mathrm{d} 1$.

\$ Number of pools or individual animals used for statistical analysis. Numbers in parentheses indicate number of fetuses in each pooled group.

than $2 \mathrm{~d}$ before birth, and values for these animals are reported for the whole gut.

Extraction of TRH and TRH-Gly from Tissues. Tissues were heated at $97^{\circ} \mathrm{C}$ for $15 \mathrm{~min}$ to inactivate endogenous TRH degrading enzymes and then processed using a Polytron tissue grinder and an Econogrind homogenizer (Randoti Glass Technology Inc., Los Angeles, CA). The homogenates were dried completely with a SVC200H Speed Vac concentrator (Savant Instruments, Hicksville, NY) and extracted twice with $2 \mathrm{~mL}$ of methanol. The methanol extracts were pooled, dried, and stored at $-20^{\circ} \mathrm{C}$. The dried extract was reconstituted in 0.5 to $2.0 \mathrm{~mL}$ of assay buffer just before assay.

Blood was placed on ice for $1 \mathrm{~h}$ to facilitate clotting. Serum separated by centrifugation was applied to a SEP-PAK C18 cartridge (Waters Associates Inc., Milford, MA) after addition of $2 \mathrm{~N}$ acetic acid $(10 \% \mathrm{vol})$. The column was washed with $20 \mathrm{mM}$ triethylamine, then eluted with an elution solvent ( 20 parts 20 $\mathrm{mM}$ triethylamine, $\mathrm{pH} 4.0,80$ parts $100 \%$ methanol), and the sample was dried and stored at $-20^{\circ} \mathrm{C}$.

TRH and TRH-Gly immunoreactivities were determined in the same tissue extracts. Recovery, calculated as percent of recovered synthetic peptide added to original tissue homogenates, was greater than $85 \%$ for TRH and $98 \%$ for TRH-Gly. Recovery of TRH and TRH-Gly from blood averaged $87 \%$ for TRH and $98 \%$ for TRH-Gly when synthetic peptides were added just before extraction. Serum degradation of these peptides was not

Table 2. Tissue and serum TRH concentrations during development in rat ${ }^{*}$

\begin{tabular}{|c|c|c|c|c|c|c|c|c|}
\hline & \multicolumn{8}{|c|}{ Age (d) } \\
\hline & -6 & -4 & -2 & 2 & 5 & 13 & 21 & 35 \\
\hline Whole brain & $\begin{array}{c}3.0 \\
(0.3)\end{array}$ & & & & & & & \\
\hline Cerebrum & & $\begin{array}{c}2.5 \\
(0.3)\end{array}$ & $<4$ & $\begin{array}{c}0.8 \\
(0.3)\end{array}$ & $\begin{array}{c}1.7 \\
(0.3)\end{array}$ & $\begin{array}{c}1.9 \\
(0.3)\end{array}$ & $\begin{array}{c}3.6 \\
(1.1)\end{array}$ & $\begin{array}{c}8.6 \\
(0.8)\end{array}$ \\
\hline Hypothalamus & & $\begin{array}{l}12 \\
(2.5)\end{array}$ & $\begin{array}{l}28 \\
(3.3)\end{array}$ & $\begin{array}{c}64 \\
(15)\end{array}$ & $\begin{array}{c}91 \\
(17)\end{array}$ & $\begin{array}{c}97 \\
(13)\end{array}$ & $\begin{array}{l}149 \\
(22)\end{array}$ & $\begin{array}{l}202 \\
(24)\end{array}$ \\
\hline Cerebellum & & $\begin{array}{c}4.7 \\
(0.8)\end{array}$ & $\begin{array}{c}5.2 \\
(0.8)\end{array}$ & $\begin{array}{c}2.5 \\
(0.1)\end{array}$ & $\begin{array}{c}6.9 \\
(0.6)\end{array}$ & $\begin{array}{c}8.0 \\
(0.8)\end{array}$ & $\begin{array}{c}5.8 \\
(0.8)\end{array}$ & $\begin{array}{l}12 \\
(1.1)\end{array}$ \\
\hline Pituitary & & & $<36$ & $\begin{array}{c}47 \\
(12)\end{array}$ & $\begin{array}{l}77 \\
(9)\end{array}$ & $\begin{array}{l}130 \\
(44)\end{array}$ & $\begin{array}{l}105 \\
(12)\end{array}$ & $\begin{array}{c}61 \\
(10)\end{array}$ \\
\hline Whole gut & $\begin{array}{c}8.3 \\
(1.9)\end{array}$ & $\begin{array}{c}7.7 \\
(3.0)\end{array}$ & & & & & & \\
\hline Stomach & & & $<6$ & $\begin{array}{c}5.2 \\
(0.8)\end{array}$ & $\begin{array}{c}3.0 \\
(0.8)\end{array}$ & $<2$ & $\begin{array}{c}3.3 \\
(0.6)\end{array}$ & $\begin{array}{c}1.9 \\
(0.3)\end{array}$ \\
\hline Duodenum & & & $<18$ & $\begin{array}{l}58 \\
(9.4)\end{array}$ & $\begin{array}{c}4.1 \\
(0.8)\end{array}$ & $\begin{array}{c}3.0 \\
(0.06)\end{array}$ & $\begin{array}{c}0.3 \\
(0.03)\end{array}$ & $\begin{array}{c}1.4 \\
(0.3)\end{array}$ \\
\hline Small gut & & & $<4$ & $\begin{array}{l}15 \\
(0.3)\end{array}$ & $\begin{array}{c}5.5 \\
(0.8)\end{array}$ & $\begin{array}{c}6.9 \\
(0.6)\end{array}$ & $\begin{array}{c}3.3 \\
(0.6)\end{array}$ & $\begin{array}{c}3.3 \\
(0.6)\end{array}$ \\
\hline Large gut & & & $<8$ & $\begin{array}{l}23 \\
(5.8)\end{array}$ & $\begin{array}{c}6.9 \\
(1.4)\end{array}$ & $\begin{array}{l}20 \\
(7.7)\end{array}$ & $\begin{array}{c}3.6 \\
(0.8)\end{array}$ & $\begin{array}{c}0.8 \\
(0.3)\end{array}$ \\
\hline Pancreas & & $<69$ & $\begin{array}{l}138 \\
(20)\end{array}$ & $\begin{array}{l}644 \\
(80)\end{array}$ & $\begin{array}{l}586 \\
(86)\end{array}$ & $\begin{array}{l}47 \\
(6.6)\end{array}$ & $\begin{array}{c}6.4 \\
(0.6)\end{array}$ & $\begin{array}{c}3.3 \\
(0.3)\end{array}$ \\
\hline Lung & $<15$ & $\begin{array}{l}12 \\
(4.1)\end{array}$ & $\begin{array}{l}14 \\
(2.2)\end{array}$ & $\begin{array}{l}12 \\
(3.3)\end{array}$ & $\begin{array}{l}50 \\
(7.7)\end{array}$ & $\begin{array}{l}55 \\
(9.9)\end{array}$ & $\begin{array}{c}1.7 \\
(0.8)\end{array}$ & $\begin{array}{c}8.6 \\
(2.8)\end{array}$ \\
\hline Heart & $<30$ & $\begin{array}{l}17 \\
(3.9)\end{array}$ & $\begin{array}{l}20 \\
(3.9)\end{array}$ & $\begin{array}{c}8.8 \\
(3.9)\end{array}$ & $\begin{array}{l}58 \\
(4.7)\end{array}$ & & $\begin{array}{l}12 \\
(4.4)\end{array}$ & $<3$ \\
\hline Liver & $\begin{array}{l}23 \\
(3.9)\end{array}$ & $\begin{array}{l}21 \\
(3.6)\end{array}$ & $\begin{array}{l}17 \\
(5.8)\end{array}$ & $\begin{array}{l}13 \\
(1.1)\end{array}$ & $\begin{array}{c}1.4 \\
(0.3)\end{array}$ & $\begin{array}{c}3.3 \\
(0.6)\end{array}$ & $\begin{array}{c}1.9 \\
(0.3)\end{array}$ & $\begin{array}{c}1.7 \\
(0.3)\end{array}$ \\
\hline Kidney & & & $<6$ & $<2$ & $\begin{array}{c}5.2 \\
(1.9)\end{array}$ & $\begin{array}{c}1.4 \\
(0.3)\end{array}$ & $\begin{array}{c}3.0 \\
(0.6)\end{array}$ & $\begin{array}{c}4.1 \\
(0.8)\end{array}$ \\
\hline Spleen & & & & $\begin{array}{c}55 \\
(11)\end{array}$ & $\begin{array}{c}9.4 \\
(1.9)\end{array}$ & & $\begin{array}{c}1.1 \\
(0.3)\end{array}$ & $\begin{array}{c}0.6 \\
(0.08)\end{array}$ \\
\hline Adrenal & & & & & & $\begin{array}{l}12 \\
(0.03)\end{array}$ & $\begin{array}{l}10.4 \\
(0.1)\end{array}$ & $\begin{array}{l}13 \\
(0.6)\end{array}$ \\
\hline Testis & & & & & $\begin{array}{c}9.4 \\
(4.4)\end{array}$ & $\begin{array}{l}2 \\
(0.08)\end{array}$ & & $\begin{array}{c}4.7 \\
(0.8)\end{array}$ \\
\hline Ovary & & & & & $<4$ & $\begin{array}{c}2.5 \\
(0.3)\end{array}$ & & $\begin{array}{c}5.8 \\
(1.1)\end{array}$ \\
\hline Serum & & & & $\begin{array}{c}80 \\
(20)\end{array}$ & $\begin{array}{l}55 \\
(9.7)\end{array}$ & $\begin{array}{l}36 \\
(7.2)\end{array}$ & $\begin{array}{l}30 \\
(6.6)\end{array}$ & $\begin{array}{l}30 \\
(7.5)\end{array}$ \\
\hline Placenta & $<20$ & $<10$ & $\begin{array}{c}5.8 \\
(0.8)\end{array}$ & & & & & \\
\hline
\end{tabular}

* Values are mean (SEM) expressed as pmol/g wet tissue or pmol/L serum. 


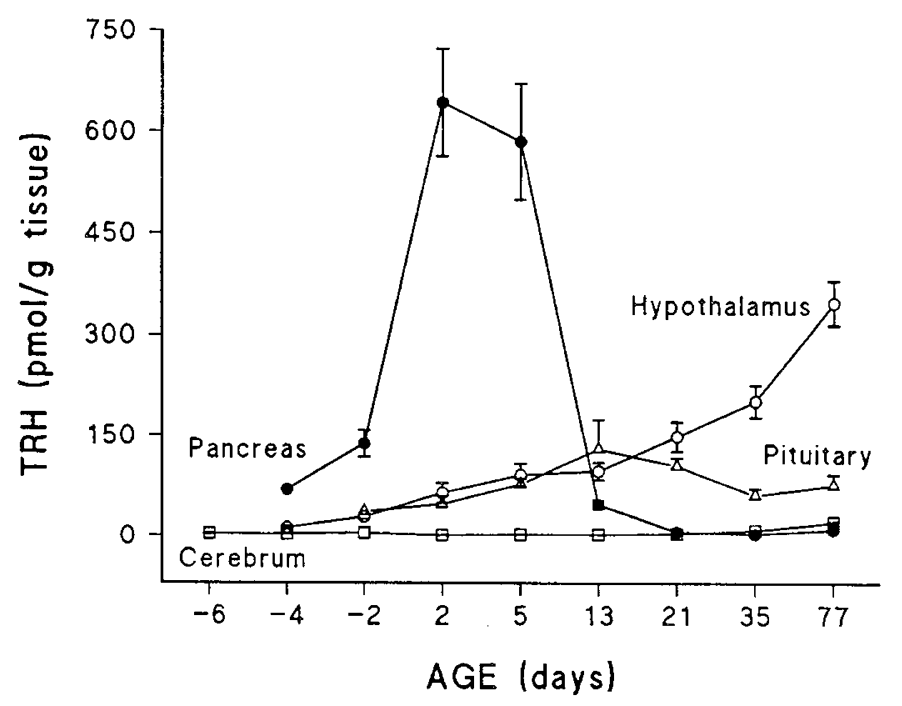

Fig. 1. Developmental changes in TRH concentrations in pancreas and neural tissues. Values are means \pm SEM. See text for details. Adult (77-d) values from reference 12 are shown for comparison.

determined. No corrections were made for recovery in the calculation of tissue peptide concentrations.

RIA for TRH and TRH-Gly. TRH. TRH was determined using our previously described methods (12). ${ }^{125}$ I-labeled TRH was prepared as described by Butler et al. (13). The TRH antiserum was obtained from rabbits after immunization with synthetic TRH conjugated with BSA (14). The TRH RIA system showed little or no cross-reaction with TRH-Gly or TRH-COOH (each $<0.01 \%$ ). Duplicate determinations were carried out for each sample. Tubes were incubated at $4^{\circ} \mathrm{C}$ for $72 \mathrm{~h}$. The smallest detectable amount of ligand in the assay system was $20 \mathrm{fmol} /$ assay tube. Within-assay and across-assay coefficients of variation were $2.2-8.7$ and $8.4-14.9 \%$, respectively.

TRH-Gly. The TRH-Gly RIA was similar to that for TRH except for substitution of TRH-Gly standards, ${ }^{125}$ I-labeled TRHGly tracer, and rabbit anti-TRH-Gly antibody as previously described (12). There was no significant cross-reaction with TRH, TRH-Lys-Arg, TRH-Gly-NH ${ }_{2}$, Arg-Glu-His-Pro-Gly, prepro-TRH (115-151) or cyclo (His-Pro) (12). The average detection limit for the assay was $26 \mathrm{fmol} /$ assay tube. The within-assay and across-assay coefficients of variation were 3.7-5.9 and 5.7$15.4 \%$, respectively.

Synthetic TRH and TRH-Gly were obtained from Peninsula Laboratories (San Carlos, CA). Goat antirabbit precipitating antibody was purchased from Antibodies Incorporated (Davis, CA).

Statistical Analysis. TRH and TRH-Gly concentrations were expressed as $\mathrm{pmol} / \mathrm{g}$ wet tissue or $\mathrm{pmol} / \mathrm{L}$ serum. When samples contained undetectable radioimmunoreactivity, the value for the sensitivity threshold of the assay was assigned to calculate mean values. Results were analyzed using one-way analysis of variance. A probability value of less than 0.05 was used as the limit of significance.

\section{RESULTS}

Developmental changes in tissue TRH concentrations. Tissue and serum TRH concentrations are shown in Table 2 and selected values are graphed in Figure 1. Concentrations of TRH in neural tissues, including cerebrum, cerebellum, and hypothalamus, were relatively low during the neonatal period and increased thereafter to adult levels. During the fetal period, relatively high TRH levels were observed in extraneural tissues including pancreas, liver, heart, and lung. TRH concentrations in liver gradually decreased by the 5 th $\mathrm{d}$ after birth, whereas in lung, heart, gut tissues, spleen, and serum, a peak of TRH concentration was observed in the early neonatal period. In kidney, adrenal, testis, and ovary, TRH immunoactivities comparable to adult levels were detectable after birth, and levels were relatively stable during the study period.

TRH concentrations in brain and pancreas during development are depicted in Figure 1. In pancreas, TRH immunoreactivity approximated $138 \pm 20 \mathrm{pmol} / \mathrm{g}$ tissue $2 \mathrm{~d}$ before birth, then sharply increased to levels of $580-650 \mathrm{pmol} / \mathrm{g}$ tissue between 2 and $5 \mathrm{~d}$ after birth. These values were 7 to 10 -fold higher than those in hypothalamus at the same time during development. After the 13th postnatal day, pancreatic TRH levels decreased and were $<10 \mathrm{pmol} / \mathrm{g}$ tissue at 21 and $35 \mathrm{~d}$. Hypothalamic TRH levels gradually increased from $12 \pm 2.5 \mathrm{pmol} / \mathrm{g}$ tissue $4 \mathrm{~d}$ before birth to $202 \pm 24 \mathrm{pmol} / \mathrm{g}$ tissue at $35 \mathrm{~d}$ of age. In cerebrum, TRH levels remained low $(<4 \mathrm{pmol} / \mathrm{g}$ tissue $)$ through $13 \mathrm{~d}$ of age and increased thereafter to $8.6 \pm 0.8 \mathrm{pmol} /$ $\mathrm{g}$ at $35 \mathrm{~d}$. Levels in cerebellum (not shown) ranged from 2.5 to $8.0 \mathrm{pmol} / \mathrm{g}$ tissue through $21 \mathrm{~d}$ and increased to $12 \mathrm{pmol} / \mathrm{g}$ at $35 \mathrm{~d}$. Pituitary TRH was quantifiable on the 2 nd postnatal day $(47 \pm 12 \mathrm{pmol} / \mathrm{g}$ tissue). Levels progressively increased, peaked at $130 \pm 44 \mathrm{pmol} / \mathrm{g}$ tissue on the $13 \mathrm{th} \mathrm{d}$, and thereafter decreased to $61 \pm 10 \mathrm{pmol} / \mathrm{g}$ tissue at $35 \mathrm{~d}$.

Developmental changes in tissue TRH-Gly concentrations. Tissue and serum TRH-Gly concentrations are shown in Table 3 and selected values are plotted in Figures 2 and 3. TRH-Gly was detected in most tissues studied; concentrations varied with age with peak concentrations usually observed between 5 and 21 postnatal days. TRH-Gly was demonstrable in placenta, whole brain and liver as early as $6 \mathrm{~d}$ before birth. During the fetal period, the highest level ( $36 \pm 5.5 \mathrm{pmol} / \mathrm{g}$ tissue) was detected in pancreas, with significant concentrations $(14-18 \mathrm{pmol} / \mathrm{g})$ observed in hypothalamus, duodenum, and heart.

Figure 2 displays the developmental changes of TRH-Gly concentrations in selected extraneural tissues (pancreas, small gut, and kidney) and serum. The mean serum TRH-Gly concentration was highest $(417 \pm 26 \mathrm{pmol} / \mathrm{L})$ on the $2 \mathrm{nd}$ postnatal day and gradually decreased to the adult level by the 35th $\mathrm{d}$ of age $(202 \pm 29 \mathrm{pmol} / \mathrm{L})$. The mean pancreatic TRH-Gly concentration was highest $(117 \pm 15 \mathrm{pmol} / \mathrm{g}$ tissue) on the 2 nd postnatal day and decreased to the $23-33 \mathrm{pmol} / \mathrm{g}$ range at 5 and $13 \mathrm{~d}$ and to the 3-11 pmol/g range at $21-35 \mathrm{~d}$. TRH-Gly levels in small gut increased from the 2 nd postnatal day to a peak on the 5 th postnatal day, when the mean value was $371 \pm 64 \mathrm{pmol} / \mathrm{g}$ tissue. Levels then fell progressively to a mean value of $33 \pm 4.8$ at 35 d. The peak TRH-Gly concentration in kidney (129 $\pm 21 \mathrm{pmol} /$ $\mathrm{g}$ tissue) occurred on the 5 th postnatal day, then decreased to 83 $\pm 18 \mathrm{pmol} / \mathrm{g}$ tissue by the $21 \mathrm{st} \mathrm{d}$ and $31 \pm 5.0 \mathrm{pmol} / \mathrm{g}$ at $35 \mathrm{~d}$.

Figure 3 summarizes the changes in TRH-Gly concentrations for selected neural tissues. TRH-Gly levels in hypothalamus, cerebrum, and cerebellum increased steadily during the neonatal period, peaking between 13 and $21 \mathrm{~d}$ of age. The mean peak values $(24$ to $62 \mathrm{pmol} / \mathrm{g})$ were lower than concentrations in kidney or small gut. The mean pituitary TRH-Gly concentration reached a peak value of $112 \pm 18 \mathrm{pmol} / \mathrm{g}$ tissue at $21 \mathrm{~d}$. This value was the highest among all tissues except serum at this age.

In other tissues (stomach, duodenum, large gut, lung, heart, liver, spleen, adrenal, testis, and ovary) TRH-Gly concentrations manifested a peak in the late neonatal period. Generally, tissue TRH-Gly levels in the perinatal period were higher than adult levels (except in pituitary, spleen, adrenal, testis, and ovary).

TRH-Gly/TRH ratios in tissues and serum. The mean values for the TRH-Gly/TRH ratios in various tissues of developing rats are summarized in Table 4 . The tissues can be roughly divided into two groups on the basis of low $(<0.80)$ and high $(>0.80)$ ratios. The tissues with relatively low ratios during the perinatal period (tissue group 1, Table 4) include liver, lung, pancreas, heart, and hypothalamus. High ratio tissues (tissue group 2, Table 4) include placenta, brain, and gut. The TRHGly/TRH ratio in serum is relatively high from $2 \mathrm{~d}$ through 35 d. Serum was not obtained from late gestation fetuses. The mean 
Table 3. Tissue and serum TRH-Gly concentrations during development in rat

\begin{tabular}{|c|c|c|c|c|c|c|c|c|}
\hline & \multicolumn{8}{|c|}{ Age (d) } \\
\hline & -6 & -4 & -2 & 2 & 5 & 13 & 21 & 35 \\
\hline Whole brain & $\begin{array}{c}6.9 \\
(1.9)\end{array}$ & & & & & & & \\
\hline Cerebrum & & $\begin{array}{c}3.3 \\
(0.5)\end{array}$ & $\begin{array}{c}5.0 \\
(0.5)\end{array}$ & $\begin{array}{l}10 \\
(1.2)\end{array}$ & $\begin{array}{l}12 \\
(0.7)\end{array}$ & $\begin{array}{l}21 \\
(2.1)\end{array}$ & $\begin{array}{l}24 \\
(3.3)\end{array}$ & $\begin{array}{c}2.1 \\
(0.5)\end{array}$ \\
\hline Hypothalamus & & $\begin{array}{l}13 \\
(1.9)\end{array}$ & $\begin{array}{l}18 \\
(3.6)\end{array}$ & $\begin{array}{l}19 \\
(2.6)\end{array}$ & $\begin{array}{l}22 \\
(3.6)\end{array}$ & $\begin{array}{l}62 \\
(4.5)\end{array}$ & $\begin{array}{c}8.8 \\
(0.7)\end{array}$ & $\begin{array}{c}9.3 \\
(1.4)\end{array}$ \\
\hline Cerebellum & & $<4$ & $<5$ & $\begin{array}{c}4.3 \\
(0.5)\end{array}$ & $\begin{array}{c}8.6 \\
(0.5)\end{array}$ & $\begin{array}{l}31 \\
(3.3)\end{array}$ & $\begin{array}{l}36 \\
(3.6)\end{array}$ & $\begin{array}{l}12 \\
(2.1)\end{array}$ \\
\hline Pituitary & & & & & $<33$ & $<43$ & $\begin{array}{l}112 \\
(18)\end{array}$ & $\begin{array}{l}21 \\
(2.1)\end{array}$ \\
\hline Whole gut & $<4$ & $\begin{array}{c}6.2 \\
(1.0)\end{array}$ & & & & & & \\
\hline Stomach & & & $\begin{array}{c}7.6 \\
(1.7)\end{array}$ & $\begin{array}{l}10 \\
(1.7)\end{array}$ & $\begin{array}{l}13 \\
(1.2)\end{array}$ & $\begin{array}{l}33 \\
(1.7)\end{array}$ & $\begin{array}{c}67 \\
(10)\end{array}$ & $\begin{array}{l}18 \\
(2.4)\end{array}$ \\
\hline Duodenum & & & $\begin{array}{l}14 \\
(2.1)\end{array}$ & $\begin{array}{l}23 \\
(3.8)\end{array}$ & $\begin{array}{l}43 \\
(5.7)\end{array}$ & $\begin{array}{l}57 \\
(7.6)\end{array}$ & $\begin{array}{l}36 \\
(4.5)\end{array}$ & $\begin{array}{l}13 \\
(2.1)\end{array}$ \\
\hline Small gut & & & $\begin{array}{l}10 \\
(1.1)\end{array}$ & $\begin{array}{l}52 \\
(7.9)\end{array}$ & $\begin{array}{l}371 \\
(64)\end{array}$ & $\begin{array}{l}157 \\
(40)\end{array}$ & $\begin{array}{l}67 \\
(9.1)\end{array}$ & $\begin{array}{l}33 \\
(4.8)\end{array}$ \\
\hline Large gut & & & $\begin{array}{c}9 \\
(0.8)\end{array}$ & $\begin{array}{l}18 \\
(2.4)\end{array}$ & $\begin{array}{l}24 \\
(4.5)\end{array}$ & $\begin{array}{l}33 \\
(9.5)\end{array}$ & $\begin{array}{l}22 \\
(4.1)\end{array}$ & $\begin{array}{c}6.2 \\
(1.7)\end{array}$ \\
\hline Pancreas & & $\begin{array}{l}36 \\
(5.5)\end{array}$ & $\begin{array}{l}22 \\
(2.4)\end{array}$ & $\begin{array}{l}117 \\
(15)\end{array}$ & $\begin{array}{l}23 \\
(6.4)\end{array}$ & $\begin{array}{l}33 \\
(3.3)\end{array}$ & $\begin{array}{l}11 \\
(1.4)\end{array}$ & $\begin{array}{c}3.1 \\
(0.7)\end{array}$ \\
\hline Lung & & $<4$ & $\begin{array}{c}5.0 \\
(0.7)\end{array}$ & $\begin{array}{l}10 \\
(1.7)\end{array}$ & $\begin{array}{l}10 \\
(0.5)\end{array}$ & $\begin{array}{l}33 \\
(6.4)\end{array}$ & $\begin{array}{l}50 \\
(3.6)\end{array}$ & $\begin{array}{c}5.7 \\
(1.9)\end{array}$ \\
\hline Heart & $<20$ & $\begin{array}{l}15 \\
(1.2)\end{array}$ & $\begin{array}{c}7.9 \\
(1.7)\end{array}$ & $\begin{array}{c}5.7 \\
(0.5)\end{array}$ & $\begin{array}{c}7.6 \\
(1.4)\end{array}$ & $\begin{array}{l}19 \\
(5.0)\end{array}$ & $\begin{array}{l}15 \\
(2.9)\end{array}$ & $\begin{array}{c}7.6 \\
(0.5)\end{array}$ \\
\hline Liver & $\begin{array}{c}5.2 \\
(1.2)\end{array}$ & $\begin{array}{c}6.4 \\
(1.0)\end{array}$ & $\begin{array}{c}5.7 \\
(0.5)\end{array}$ & $\begin{array}{c}9.8 \\
(1.4)\end{array}$ & $\begin{array}{l}20 \\
(2.4)\end{array}$ & $\begin{array}{l}40 \\
(3.1)\end{array}$ & $\begin{array}{l}24 \\
(3.1)\end{array}$ & $\begin{array}{l}29 \\
(5.7)\end{array}$ \\
\hline Kidney & & $<19$ & & $\begin{array}{l}26 \\
(6.7)\end{array}$ & $\begin{array}{l}129 \\
(21)\end{array}$ & $\begin{array}{l}33 \\
(9.1)\end{array}$ & $\begin{array}{c}83 \\
(18)\end{array}$ & $\begin{array}{l}31 \\
(5.0)\end{array}$ \\
\hline Spleen & & & $<12$ & $\begin{array}{c}9.5 \\
(1.7)\end{array}$ & $\begin{array}{c}9.8 \\
(2.1)\end{array}$ & $\begin{array}{l}29 \\
(1.7)\end{array}$ & $\begin{array}{l}31 \\
(3.3)\end{array}$ & $\begin{array}{l}20 \\
(3.1)\end{array}$ \\
\hline Adrenal & & & & & & & $\begin{array}{l}26 \\
(4.5)\end{array}$ & $\begin{array}{c}8.1 \\
(0.5)\end{array}$ \\
\hline Testis & & & & & $<8$ & & $\begin{array}{l}16 \\
(0.7)\end{array}$ & \\
\hline Ovary & & & & & & & $\begin{array}{l}11 \\
(1.2)\end{array}$ & $\begin{array}{c}3.6 \\
(0.7)\end{array}$ \\
\hline Serum & & & & $\begin{array}{l}417 \\
(26)\end{array}$ & & $\begin{array}{l}352 \\
(12)\end{array}$ & $\begin{array}{l}293 \\
(38)\end{array}$ & $\begin{array}{c}202 \\
(29)\end{array}$ \\
\hline Placenta & $\begin{array}{c}9.3 \\
(0.7)\end{array}$ & $\begin{array}{c}8.6 \\
(1.0)\end{array}$ & $\begin{array}{c}6.0 \\
(0.5)\end{array}$ & & & & & \\
\hline
\end{tabular}

* Values are mean (SEM) expressed as pmol/g tissue or pmol/L serum.

TRH-Gly/TRH ratios in liver, pancreas, and hypothalamus are summarized in Figure 4 with the corresponding TRH concentrations. In liver, the TRH-Gly/TRH ratio was low during the period from $6 \mathrm{~d}$ before birth to $2 \mathrm{~d}$ after birth $(0.23$ to 0.75$)$, increased markedly to values in the 12 to 17 range between 5 and $35 \mathrm{~d}$, and then fell to the adult level of 3.1. In pancreas, the TRH-Gly/TRH ratio decreased to a nadir value of 0.05 at $5 \mathrm{~d}$, increased to a peak value of 2 at $21 \mathrm{~d}$, and then fell to the adult level of 0.8 . The TRH-Gly/TRH ratio in hypothalamic tissue was 1.1 at $4 \mathrm{~d}$ before birth, remained in the 0.2 to 0.7 range between -2 and $13 \mathrm{~d}$ of life, and decreased progressively thereafter to the adult level of 0.03 . The changes in the TRH-Gly/ TRH ratio in these tissues were generally inversely correlated with the respective tissue TRH-Gly concentrations.

\section{DISCUSSION}

The TRH and TRH-Gly RIA systems used in our study were quite specific (12). Moreover, by HPLC analysis, tissue and serum TRH and TRH-Gly immunoreactivities coeluted with synthetic peptide standards (12). In our study we detected TRH and TRH-Gly immunoreactivities in most rat tissues. It is possible that blood contamination of the tissue extracts contributed to the measured tissue levels of TRH and TRH-Gly, inasmuch as high concentrations of the peptides were observed in serum during the postnatal period. Although there are no data regarding the amount of serum in developing rat tissues and we did not measure $\mathrm{Hb}$ concentrations in the extracts, we calculated the possible contribution of the blood peptide levels to the measured tissue concentrations of TRH and TRH-Gly using the data of D'Ercole et al. (15); these authors estimated blood contamination of adult rat tissues using measurements of tissue $\mathrm{Hb}$ levels. Using these estimates of blood contamination of tissues, the estimated concentration of TRH-Gly derived from blood in brain, heart, lung, liver, and kidney ranged from 0.2 to $0.002 \%$ of the total measured peptide. The range for TRH was 0.02 to $0.003 \%$. Even considering that the blood content of fetal and neonatal tissues might be greater than that in adult tissues, these data suggest that the contribution of sequestered blood peptide to the tissue levels of TRH and TRH-Gly in our study was insignificant.

TRH immunoreactivity in our study was characterized from late fetal life to 35 postnatal days. At this time measured values 


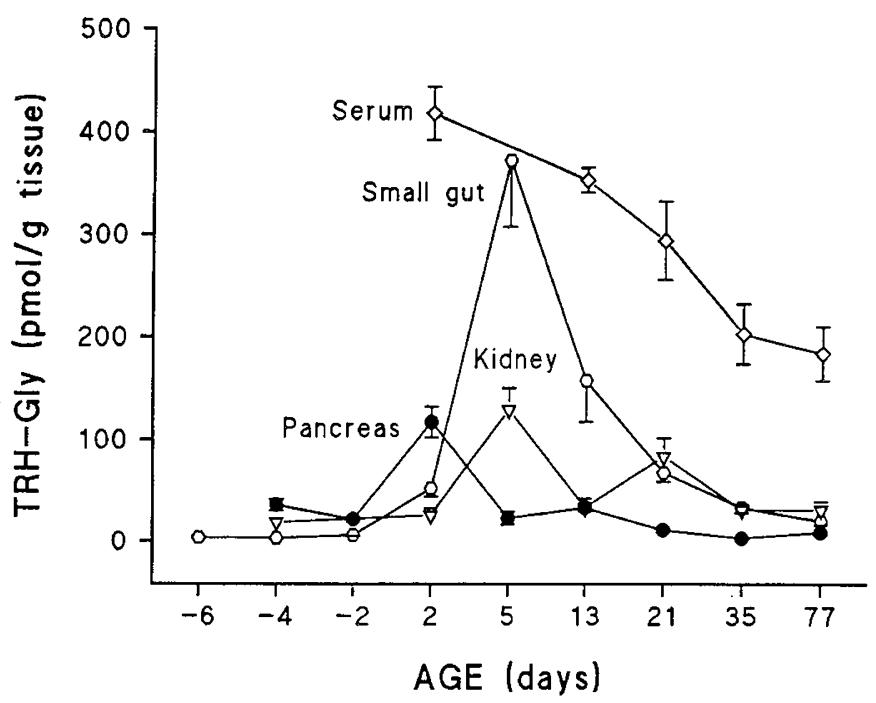

Fig. 2. Developmental changes of TRH-Gly concentration in serum, pancreas, kidney, and small gut. Values are means \pm SEM. See text for details. Adult (77-d) values from reference 12 are shown for comparison.

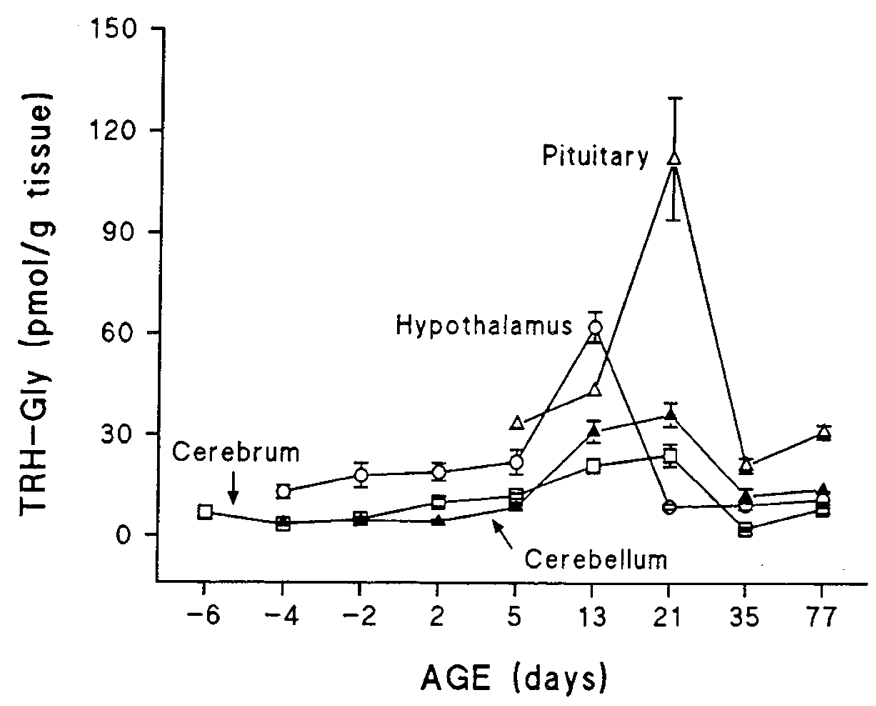

Fig. 3. Developmental changes of TRH-Gly concentration in neural tissues. Values are means \pm SEM. See text for details. Adult (77-d) values from reference 12 are shown for comparison.

were very similar to concentrations in adult animals in our laboratory (12). TRH immunoreactivity was quantifiable in whole brain $6 \mathrm{~d}$ before birth ( 15 gestational days). In hypothalamus, TRH was detected $4 \mathrm{~d}$ before birth (17 gestational days), but levels remained low during the early weeks of life. In earlier studies, TRH was detectable by RIA in whole brain between 12 and 17 fetal days (16-19). The first neurons containing TRH mRNA appear in the lateral hypothalamus on the 14th $d$ of gestation (20). Our results are in agreement with these reports as well as other data (21-24).

Relatively high tissue TRH levels, exceeding adult values, were observed in several developing tissues, including pancreas, liver, lung, heart, and large and small gut, and in serum (12). Highest levels were observed in pancreas where we detected TRH immunoreactivity $2 \mathrm{~d}$ before birth (19 gestational days). TRH levels in pancreas rapidly increased to a peak between 2 and 5 postnatal days, when concentrations exceeded those in hypothalamus nearly 10-fold (Table 2, Fig. 1). Levels decreased thereafter to values comparable to those in adult rats (12). This developmental change in pancreatic TRH is consistent with previous reports $(9$, 19). TRH mRNA and other TRH precursor peptides have been described in the pancreas of the perinatal rat. Pancreatic TRH
Table 4. TRH-Gly/TRH concentration ratios in various tissues

\begin{tabular}{|c|c|c|c|c|c|c|c|c|}
\hline & \multicolumn{8}{|c|}{ Age (d) } \\
\hline & -6 & -4 & -2 & 2 & 5 & 13 & 21 & 35 \\
\hline \multicolumn{9}{|l|}{ Tissue group 1} \\
\hline Liver & 0.23 & 0.30 & 0.34 & 0.75 & 14.3 & 12.1 & 12.6 & 17.0 \\
\hline Lung & & 0.33 & 0.36 & 0.83 & 0.20 & 0.60 & 29.4 & 0.66 \\
\hline Pancreas & & $<0.52$ & 0.16 & 0.18 & 0.04 & 0.70 & 1.72 & 0.94 \\
\hline Heart & $<0.67$ & 0.88 & 0.40 & 0.65 & 0.13 & & 1.25 & $>2.55$ \\
\hline $\begin{array}{l}\text { Hypothala- } \\
\text { mus }\end{array}$ & & 1.08 & 0.64 & 0.30 & 0.24 & 0.64 & 0.06 & 0.05 \\
\hline \multicolumn{9}{|l|}{ Tissue group 2} \\
\hline Placenta & & $>0.86$ & 1.03 & & & & & \\
\hline Whole brain & 2.3 & & & & & & & \\
\hline Cerebrum & & 1.3 & $>1.25$ & 5.56 & 7.06 & 11.1 & 6.67 & 0.24 \\
\hline Cerebellum & & $<0.85$ & $<0.96$ & 1.72 & 1.25 & 3.88 & 6.21 & 1.00 \\
\hline Whole gut & $<0.48$ & 0.80 & & & & & & \\
\hline Stomach & & & 1.3 & 1.92 & 4.33 & 11.5 & 20.3 & 9.47 \\
\hline Duodenum & & & $>0.78$ & 2.52 & 10.5 & 19.0 & 120.0 & 9.28 \\
\hline Small gut & & & & 3.47 & 67.5 & 22.8 & 20.3 & 10.0 \\
\hline Large gut & & & & 0.78 & 3.48 & 1.65 & 6.11 & 7.75 \\
\hline Serum & & & & 5.21 & & 6.40 & 9.76 & 6.73 \\
\hline
\end{tabular}

mRNA has been detected at 19 gestational days with highest expression at birth and lower levels at 14 postnatal days (25). Prepro-TRH peptides have been characterized in the $\beta$-cells of islets of Langerhans at $d 21$ of gestation (10). The concentrations of these peptides increased rapidly after birth, reaching maximum levels at 2-4 postnatal days (11). Pancreatic $\alpha$-amidating monooxygenase activity also parallels the prepro-TRH and TRH peptide levels (26). Proposed physiologic roles of pancreatic TRH in the perinatal period are 1) to inhibit the action of somatostatin $(27), 2)$ to modulate islet development, or 3) to modulate exocrine function (10).

TRH-Gly was also widely distributed in developing rat tissues. The pattern of distribution was comparable to that previously reported in adult rats $(5,12,28)$. In general, levels of both TRH and TRH-Gly were elevated in tissues obtained during the perinatal period. The tissues with relatively high TRH-Gly levels (14-36 pmol/g tissue) in the fetal period were hypothalamus, pancreas, gut tissues, and heart. After birth, peaks of TRH-Gly concentrations $(>100 \mathrm{pmol} / \mathrm{g}$ tissue or $\mathrm{pmol} / \mathrm{L}$ serum) were observed in serum and pancreas (at d 2); small gut, kidney, and hypothalamus (at d 5); and pituitary gland (at d 21). Among these tissues, changes of TRH-Gly levels paralleled those of TRH in serum, pancreas, and small gut. The significance of high serum TRH-Gly concentrations but low TRH levels in developing rat tissues also remains unclear. However, such dramatic changes in peptide concentrations suggest that TRH-Gly may exert specific functions via endocrine or paracrine routes. Biologic activities of TRH-Gly have been reported recently in adult rats: synthetic TRH-Gly injected intracisternally stimulated gastric acid secretion (29), as well as TSH release (30). A biologic role for TRHGly in developing animals has not been shown. TRH-Gly has been shown to increase prolactin secretion in anorectic women; this response was not observed in matched control females or in patients with uremia, acromegaly, or prolactinoma (31).

Conversion of TRH-Gly to TRH is mediated by an $\alpha$-amidating enzyme (peptidyl glycine $\alpha$-amidating monooxygenase) (3). The inverse relationship between the TRH-Gly/TRH ratio and TRH concentration observed in hypothalamus, pancreas, and liver (Fig. 4) suggests that the activity of this enzyme may be a rate-limiting step in TRH biosynthesis, and the dramatic changes in the TRH-Gly/TRH ratio during development in these tissues suggest developmental regulation of this enzyme system.

On the basis of these observations, we conclude that tissue levels of TRH and TRH-Gly are developmentally regulated. Assuming that TRH-Gly is a marker for tissue TRH synthesis, our results suggest a progressive change during development in 

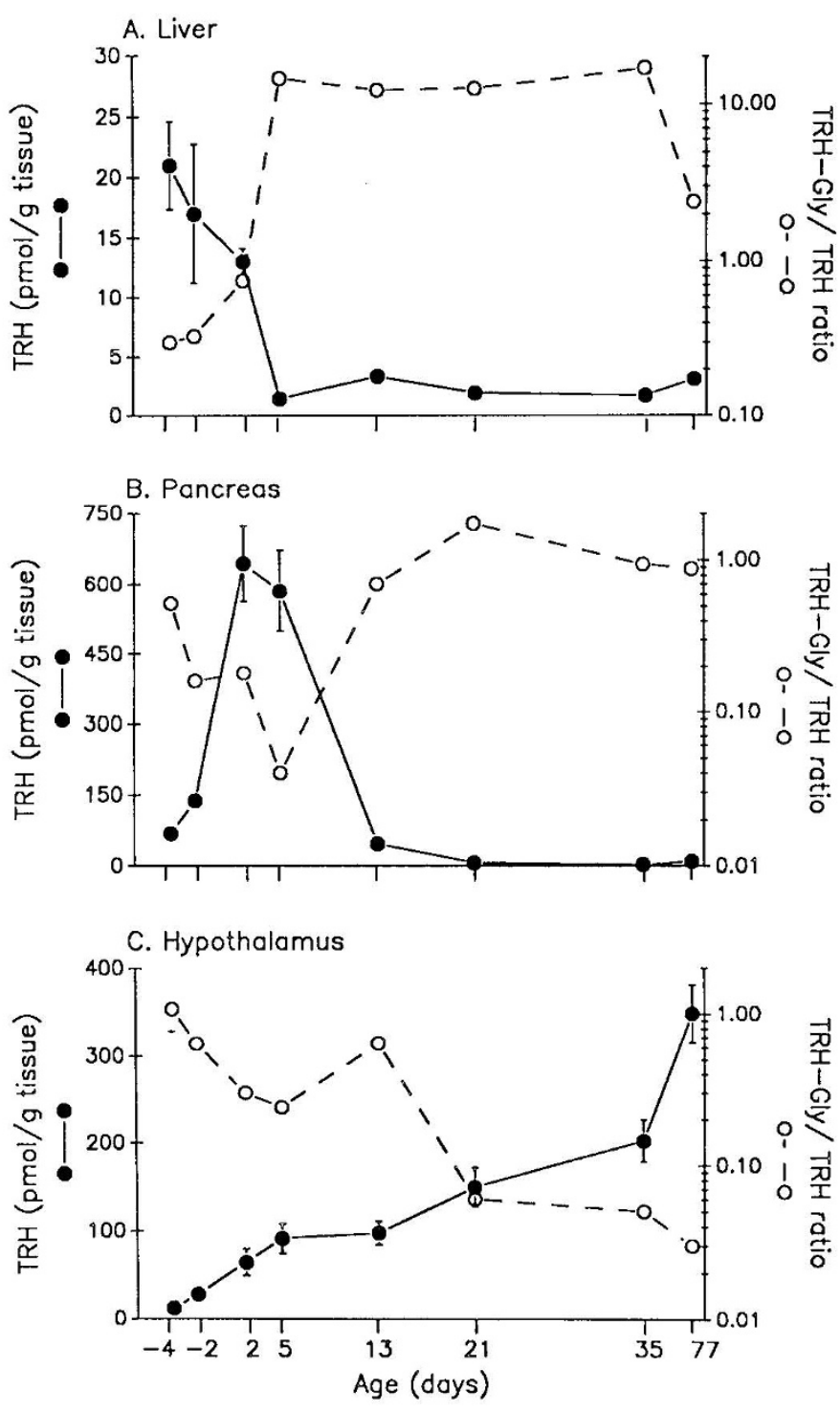

Fig. 4. Changes in mean TRH-Gly/TRH-ratios and TRH concentrations in liver (upper panel), pancreas (middle panel), and hypothalamus (lower panel). Values are mean \pm SEM. TRH-Gly/TRH ratios are plotted as open circles and dashed lines; TRH values are plotted as closed circles and solid lines. Adult (77-d) values from reference 12 are shown for comparison.

the major tissue site of TRH biosynthesis. Given its relatively large mass, relatively high TRH concentration, and low TRHGly/TRH ratio, liver seems to be the major site of TRH synthesis in the fetus. During the neonatal period, the pancreas and other gut tissues are major TRH-producing tissues (Table 2, Fig. 4). After $3 \mathrm{wk}$, the major site of TRH biosynthesis is the hypothalamus (Table 2, Fig. 4). Serum levels of TRH and TRH-Gly seem to reflect multiple tissue sources, and the predominant circulating species is TRH-Gly (Table 4). This is also true in adult animals, where the high TRH-Gly/TRH ratio reflects a predominantly nonhypothalamic tissue source of peptide (12).

\section{REFERENCES}

1. Lechan RM, Wu P, Jackson IMD, Wolf H, Cooperman S, Mandel G, Goodman RH 1986 Thyrotropin-releasing hormone precursor: characterization in rat brain. Science 231:159-161

2. Wu P 1989 Identification and characterization of TRH-precursor peptides. In: Metcalf G, Jackson IMD (eds) Thyrotropin-releasing hormone-biomedical significance. Ann NY Acad Sci 553:60-70
3. Bradbury AF, Finnie MDA, Smyth DG 1982 Mechanism of C-terminal amide formation by pituitary enzymes. Nature 298:686-688

4. Fischer WH, Spiess J 1987 Identification of a mammalian glutaminyl cyclase converting glutamyl into pyroglutamyl peptides. Proc Natl Acad Sci USA $84: 3628-3632$

5. Simard M, Pekary AE, Smith VP, Hershman JM 1989 Thyroid hormones modulate thyrotropin-releasing hormone biosynthesis in tissue outside the hypothalamic-pituitary axis of male rats. Endocrinology 125:524-531

6. Theodoropoulos T, Braverman LE, Vagenakis AG 1979 Thyrotropin-releasing hormone is not required for thyrotropin secretion in the perinatal rat. J Clin Invest 63:588-594

7. Neary JT, Kieffer JD, Federico P, Maloof HMF 1976 Thyrotropin releasing hormone: development of inactivation system during maturation of the rat. Science 193:403-405.

8. Koivusalo F, Leppaluoto J 1979 High TRF immunoreactivity in purified pancreatic extracts of fetal newborn rats. Life Sci 24:1655-1658

9. Engler D, Scanlon MF, Jackson IMD 1981 Thyrotropin-releasing hormone in the systemic circulation of the neonatal rat is derived from the pancreas and other extraneural tissues. J Clin Invest 67:800-806

10. Wu P, Jackson IMD 1988 Identification, characterization and localization of thyrotropin-releasing hormone precursor peptides in perinatal rat pancreas. Regul Pept 22:347-360

11. Dutour A, Bulant M, Giraud P, Nicolas P, Vaudry H, Oliver C 1989 ProTRH-connecting peptides in the rat pancreas during ontogenesis. Peptides $10: 523-527$

12. Fuse Y, Polk DH, Lam RW, Fisher DA 1990 Thyrotropin releasing hormone (TRH) and precursor peptide (TRH-Gly) in adult rats. Endocrinology 127:2501-2505.

13. Butler SR, Lam RW, Fisher DA 1984 Iodination of thyroliberin by use of iodogen. Clin Chem 30:547-548

14. Lombardi G, Panza N, Cei S, Cosimato F, Minozzi M 1978 Radioimmunoassay of thyrotropin-releasing hormone (TRH) in normal subjects, in abnormal thyroid states and under catecholaminergic influences. Acta Endocrinol (Copenh) 87:70-79

15. D'Ercole AJ, Stiles AD, Underwood LE 1984 Tissue concentrations of somatomedin C: further evidence for multiple sites of synthesis and paracrine or autocrine mechanisms of action. Proc Natl Acad Sci USA 81:935-939

16. Oliver C, Eskay RL, Porter JC 1980 Developmental changes in brain TRH and in plasma TSH and prolactin levels in the rat. Biol Neonate 37:145-152

17. Nemerski A, Grouselle D, Faivre-Bauman A, Tixier-Vidal A 1985 Developmental changes of thyroliberin (TRH) in the rat brain. Neurosci Lett 53:279284

18. Schaeffer JM, Brownstein MJ 1980 Ontogeny of TRH-like material in several regions of the rat brain. Brain Res 182:207-210

19. Lamberton RP, Lechan RM, Jackson IMD 1984 Ontogeny of thyrotropinreleasing hormone and histidyl proline diketopiperazine in the rat central nervous system and pancreas. Endocrinology 115:2400-2405

20. Burgunder J, Taylor T 1989 Ontogeny of thyrotropin-releasing hormone gene expression in the rat diencephalon. Neuroendocrinology 49:631-640

21. Dussault JH, Labrie F 1974 Development of hypothalamic-pituitary-thyroid axis in the neonatal rat. Endocrinology 97:1321-1324

22. Ojeda SR, Krulich L, Jameson HE 1976 Developmental patterns of plasma and pituitary TSH and prolactin and hypothalamic TRH in the female rat. Endocr Res Commun 3:387-406

23. Martino E, Seo H, Lernmark A, Refetoff S 1980 Ontogenetic patterns of thyrotropin-releasing hormone-like material in rat hypothalamus, pancreas, and retina: selective effect of light deprivation. Proc Natl Acad Sci USA $77: 4345-4348$

24. Gayo L, Bonet B, Herranz AS, Iglesias R, Toro MJ, Montoya E 1986 Postnatal development of brain TRH, serum TSH and thyroid hormones in the male and female rat. Acta Endocrinol (Copenh) 112:7-11

25. Dutour A, Giraud P, Kowalski C, Quafic LH, Salers P, Strbac V, Oliver C 1987 Ontogenesis of TRH mRNA in the rat pancreas. Biochem Biophys Res Commun 146:354-360

26. Quafik L, Giraud P, Salers P, Dutour A, Castanas E, Boudouresque F, Oliver C 1987 Evidence for high peptide alpha-amidating activity in the pancreas from neonatal rats. Proc Natl Acad Sci USA 84:261-264

27. Hokfelt T, Tsuro Y, Ulfhake B, Cullheim S, Arvudsson U, Foster GA Schultzberg M, Schalling M, Arborelius L, Freedman J, Post C, Visser T 1989 Distribution of TRH-like immunoreactivity with special reference to coexistence with other neuroactive compounds. Ann NY Acad Sci 553:76105

28. Simard M, Pekary AE, Smith P, Hershman JM 1989 Thyroid hormone modulation of TRH precursor levels in rat hypothalamus, pituitary, thyroid and blood. Peptides 10:145-155

29. Stephens RL, Pekary AE, DiStephano III JJ, Landaw E, Tache Y 1989 Intracisternal injection of TRH precursor, TRH-glycine, stimulates gastric acid secretion in rats. Regul Pept 25:51-60

30. Pekary AE, Stephens R, Simard M, Hershman JM 1988 Thyrotropin (TSH) release in rats after intracisternal injection of a thyrotropin-releasing hormone precursor. Clin Res 36:126A(abstr)

31. Mori M, Murakami M, Satoh T, Miyashita K, Iriuchijima T, Yamada M, Inukai T, Kobayashi I 1990 A possible direct precursor of thyrotropinreleasing hormone, pGlu-His-Pro-Gly, stimulates prolactin secretion in anorexia nervosa. J Clin Endocrinol Metab 71:252-255 